\title{
SUNNAH DAN KEDUDUKAN MUHAMMAD DALAM PANDANGAN MUHAMMAD SYAHRUR
}

\author{
Muhammad Anshori \\ Program Doktoral Konsentrasi Studi Al-Qur'an dan Hadis \\ Universitas Islam Negeri Sunan Kalijaga Yogyakarta \\ anshori92@gmail.com
}

Diterima 15 Juli 2018 | Direview 27 Agustus 2018| Diterbitkan 01 Desember 2018

\begin{abstract}
This article discusses on contextualist understanding about sunnah or hadith. One of the contemporary Muslim thinker who is studied by muslim scholars is Muhammad Syahrür. According to Syahrür, the sunnah was the initial ijtihad of Mubammad to overcome the problems that existed at that time, so it must be dynamic. Among the interesting thoughts of Syahrür is his division of the concept of Mubammad's obedience and position. There are two forms of obedience to Mubammad: obedience that is not directly related to Allah (al-thä'ah al-munfashilab) and directly related to Allah (al-thä'ah al-muttashilab). In examining the hadith of the Prophet, Syahrür did not understand in a textuality, but he studied the position of Muhammad when the hadith was spoken. He divided the position of Mubammad into three poins; as human beings, the Prophet, and the Apostle. The Hadith or Sunna will be universally applicable when Muhammad is based as an Apostle. Syahrür's understanding of a hadith is very bumanity because he is not directed to sanad studies, but rather to matan hadith.
\end{abstract}

Keywords: The concept of Sunnah, the position of Mubammad, and Muhammad Syahrür

\begin{abstract}
Abstrak
Artikel ini membahas pemahaman kontekstualis tentang sunnah atau hadis. Salah satu pemikir Muslim kontemporer yang dipelajari oleh sarjana muslim adalah Muhammad Syahnür. Menurut Syahrür, sunnah adalah ijtihad awal Mubammad untuk mengatasi masalah yang ada pada saat itu, sehingga harus dinamis. Di antara pemikiran Syahrür yang menarik adalah pembagian konsep ketaatan dan posisi Muhammad. Ada dua bentuk ketaatan kepada Muhammad: ketaatan yang tidak. berbubungan langsung dengan Allah (al-thä'ah al-munfashilab) dan langsung terkait dengan Allah (al-tha'ah al-muttashilab). Dalam memeriksa hadits Nabi, Syahrür tidak mengerti secara tekstualitas, tetapi ia mempelajari posisi Muhammad ketika hadis tersebut diucapkan. Dia membagi posisi Muhammad menjadi tiga poins; sebagai manusia, Nabi, dan Rasul. Hadis atau Sunah akan berlaku secara universal ketika Muhammad didasarkan sebagai seorang Rasul. Pemahaman Syahrür tentang sebuah hadits adalah sangat manusiawi karena ia tidak diarabkan untuk mempelajari sanad, tetapi lebih kepada hadits matan.
\end{abstract}

Kata Kunci: Konsep Sunnah, Kedudukan Muhammad, and Muhammad Syahrūr.

\section{Pendahuluan}

Dari masa ke masa, pemikiran dalam studi Islam (Islamic Studies) terus berkembang dengan berbagai macam ragamnya. Studi Islam memang sangat luas karena banyak hal yang terkait dengan Islam dibahas di dalamnya. Selain cakupan kajiannya yang luas, tokoh-tokoh dalam studi Islam juga banyak sesuai dengan spesialisasi masing-masing. Salah satu hal yang dibahas dalam studi Islam adalah tentang kosep sunnah yang sampai sekarang masih dijadikan sebagai slogan oleh kaum Muslimin. Ketika mendengar kata sunnah, tentu yang terlintas dalam benak dan pikiran kita adalah tentang perilaku Nabi Muhammad. Dalam studi Hadis (Ulumul Hadis), istilah sunnah sama maknanya dengan hadis dari segi terminologi. Tetapi jika merujuk kepada al-Qur'an, makna sunnah akan berbeda dengan makna yang dipakai dalam terminologi hadis. Salah satu tokoh yang membahas tentang konsep sunnah adalah Muḥammad Syaḥrūr.

Muhammad Syaḥūr merupakan salah satu pemikir Islam dari Syiria yang dianggap kontroversial oleh beberapa sarjana Muslim. Kritikan yang diarahkan kepadanya ada yang positif (pro) dan tentu pula ada yang negatif (kontra). Dalam dunia akademik, hal tersebut sah-sah saja asalkan sesuai dengan argumen-argumen yang bisa dipertanggung jawabkan secara ilmiah kademik pula. Tidak ada satu pemikiran pun di dunia melainkan akan ada tanggapan dan kritikan yang ditujukan kepadanya. Kebenaran yang ada sekarang sebagian besar bersifat relatif, tidak absolut. Penafsiran apapun pasti ada hal-hal yang melingkupi atau yang melatar belakanginya. Keadaan sosial, ekonomi, pilitik, budaya, dan sebagainya tentu 
juga mempengaruhi lahirnya pemikiran itu. Tak terkecuali dengan konsep sunnah yang dipahami ulang oleh Syahrūr dalam beberapa bukunya.

Tulisan ini akan mengkaji tentang konsep sunnah dan hal-hal yang terkait dengannya menurut Muhammad Syaḥūr. Konsep sunnah ini memang selalu menarik untuk dikaji karena dengan menggunakan pendekatan atau cara pandang yang baru, tentu akan melahirkan pemikiran yang berbeda. Hal tersebut menarik karena konsep sunnah serta tifologinya bisa dimaknai ulang dengan pemahaman yang tidak kaku. Meskipun sudah banyak yang mengkaji pemikiran Muḥammad Syaḥrūr, tetapi masih ada beberapa hal yang harus diteliti.

Tulisan ini diharapkan bisa memberi pemahaman yang baru dalam kajian hadis (qiräah muntijah), bukan hanya mengulangi pembahasan terdahulu (qiä'ah mutakarrirah). Harus diakui bahwa apapun yang diteliti sekarang pasti sudah ada yang sudah melakukan sebelumnya. Itulah sebabnya dalam sebuah penelitian ada istilah kajian pustaka atau telaah pustaka yang berfungsi untuk menelusuri penelitian atau kajian sebelumnya dan mencari hal-hal yang belum tersentuh atau dikaji. Sebelum membahas pemikiran seorang tokoh tentu akan dibahas tentang biografinya terlebih dahulu supaya diketahui latar belakang pemikiran.

\section{Biografi Singkat Muḥammad Syaḥrūr}

Muḥammad Syaḥrūr dilahirkan di Damaskus, Syiria pada 11 April 1938. Pendidikan dasar dijalani di tanah kelahirannya. Pendidikan Teknik Sipil ditempuh di Moskow (19591964), kemudian mengajar pada Fakultas Teknik Sipil Universitas Damaskus. Pada tahun 1969, Syahrūr meraih gelar Master, dan Doktor pada tahun 1972 dengan spesialisasi Mekanika Pertanahan dan Fondasi. Ia mengajarkan Mekanikan Pertanahan dan Geologi pada almamaternya. Bersama bebera rekannya di Fakultas, Syaḥūr membuka Biro Konsultasi Teknik. Ia juga pernah menjadi tenaga ahli pada al-Saud Consult Kerajaan Saudi Arabia pada tahun 1982-1983.

Diantara karya Syahrūr adalah al-Kitāb wa al-Qur'ān: Qiräah Mu'äshirah, ${ }^{1}$ yang banyak mengundang pro-kontra antara sarjana Muslim di Timur Tengah, Handasah al-Asāsät (Teknik Fondasi Bangunan), Handasah al-Turbah (Teknik Pertanahan), Diräsah Islämīyah Mu'ạsirah fì alDaulah wa al-Mujtama' (Wawasan Islam Kontemporer tentang Negara \& Masyarakat, 1994), al-Isläm wa al-İmàn: Manґ̧ümah al-Qiyam (buku ini mengkritik wacana klasik tentang rukun Islam dan Iman, 1996), Nahwa Ushül al-Jadidah li al-Fiqh al-Mar'ah (2000), al-Sunnah alRasülìyah wa al-Sunnah al-Nabawiyah; Ru'yah Jadidah (2012) dan beberapa artikel lainnya.

Ada tiga fase yang dilalui oleh Muhammad Syahrūr sehingga pemikirannya bisa seperti melejit di kancah pemikiran internasional. ${ }^{2}$ Fase pertama (1970-1980), fase ini dimulai ketika Syaḥrūr mengambil studi di Irland National University, Dublin, Irlandia. Pasa saat itu, dia mengambil program master dan doktor di bidang Teknik Sipil. Fase ini merupakan fase murāja'āt terhadap warisan pemikiran ulama klasik dan sekaligus merupakan fase peletakan dasar-dasar metodologi dalam memahami al-Qur'an.

Syahrūr melihat bahwa Islam yang diformat melalui pemikiran-pemikiran keislaman klasik, baik melalui mazhab-mazhab fiqih maupun teologi, cenderung dianggap sebagai ideologi sehingga menyebabkan mandeknya pemikiran keislaman. Oleh karena itu, harus ada keberanian intelektual untuk mereformasi pemikiran-pemikiran lama tersebut.

${ }^{1}$ Kritik yang baik terhadap kitab ini telah dilakukan oleh Māhir al-Munajjad dalam bukunya Munaqasyāt al-Isykeäliyah al-Manhajìyah fì al-Kitäb wa al-Qur'ān: Diräsab Naqdīyah. Buku ini telah diterjemahkan ke dalam bahasa Indonesia oleh Burhanuddin Dzikri dengan judul Membongkar Ideologi Tafsir Al-Qur'an Kontemporer (Yogyakarta: Elsaq Press, cet-I, 2008).

${ }^{2}$ Biografi Muhammad Syahrūr penulis ringkas dari Abdul Mustaqim, Epistemologi Tafsir Kontemporer (Yogyakarta: LKiS, cet-I, 2010), dan Muhyar Fanani, Fiqih Madani: Konstruksi Hukum Islam di Dunia Modern (Yogyakarta: LKiS, cet-I, 2010). 
Fase Kedua (1980-1986), Fase ini dimulai sejak Muḥammad Syahrūr berada di Uni Soviet ketika ia bertemu dengan gurunya, Ja'far Dakk al-Bāb. Sejak saat itu, Syaḥrūr mulai serius mendalami ilmu bahasa di bawah bimbingan gurunya itu. Ja'far Dakk al-Bāb mempekenalkan kepada Syahrūr berbagai teori linguistik serta tokoh-tokohnya, seperti alFarrà' (w. 207 H), Abū 'Alī al-Fārisī (w. 377 H), Ibn Jinnī (w. 392 H) sampai kepada 'Abdul Qāhir al-Jurjānī (w. 392 H). Dengan teori-teori itu, Syaḥrūr berhasil melakukan peninjauan ulang terhadap ayat-ayat al-dzikr (al-Qur'an) dan merumuskan konsep-konsep dasar dalam kajian al-Qur'an. Konsep atau istilah-istilah yang dibuat Syahrūr memang unik dan maknanya berbeda dengan pemahaman ulama sebelumnya. Di antara istilah baru yang dikenalkan olehnya adalah al-Kitäb, ${ }^{3}$ al-Qur'ān, al-Furqān, ${ }^{4}$ al-dżikr, ${ }^{5}$ Imām Mubin, ${ }^{6}$ Umm alKitäb, dan Laụ Mahfǚrh. ${ }^{7}$

Jika selama ini ulama-ulama klasik menyamakan istilah-istilah tersebut sebagai namanama al-Qur'an, maka Syaḥūr mengatakan bahwa istilah-istilah itu memiliki perbedaan. Tentu perbedaan dalam memahami konsep tersebut akan berimplikasi terhadap penafsiran suatu ayat. Fase ketiga adalah fase penyusunan akhir (1986-1990). Pada fase ini karya-karya Muḥammad Syaḥrūr mulai dikenal banyak orang sehingga namanya menjadi terkenal.

Sebagaimana disebutkan di atas bahwa Muḥammad Syaḥrūr merupakan salah satu pemikir produktif yang telah melahirkan beberapa karya penting dalam pemikiran al-Qur'an dan hadis. Dalam tulisan ini, penulis akan membahas tentang kedudukan Muhammad ketika menyampaikan suatu hadis sehingga bisa diketahui apakah ucapan atau perbuatan Muhammad itu menjadi syariat atau tidak.

\section{Konsep Pemikiran Hadis Muḥammad Syaḥrūr}

Perlu ditegaskan di sini bahwa yang dimaksud dengan sunnah oleh Muhammad Syahrūr adalah hadis menurut ulama hadis. Dengan konsep tersebut maka tidak akan terjadi kerancauan dalam penggunaan istilah. Harus diakui juga bahwa hadis yang belum dikodifikasi disebut sunnah, sedangkan sunnah yang sudah dikodifikasi namanya hadis. Untuk konteks sekarang sunnah sama dengan hadis. Ada empat prinsip-prinsip yang harus dipahami tentang konsep sunnah dalam pendangan Muḥammad Syaḥūū. Pertama, apa yang dilakukan, disabdakan, dan ditetapkan oleh Nabi bukan merupakan wahyu.

Adapun surat al-Najm ayat 3-4 yang selalu dijadikan rujukan oleh orang yang mengatakan bahwa apa saja yang berasal dari Muhammad merupakan wahyu merupakan pemahaman yang salah terhadap al-Qur'an. Ayat ketiga dari surat itu justru memuji Muhammad yang tidak mengikuti hawa nafsu ketika berbicara. Sedangkan damir huwa pada

\footnotetext{
${ }^{3}$ Semua ayat mushaf mulai dari surat al-Fātiḥah sampai al-Nās yang merupakan kumpulan tema yang diwahyukan oleh Allah kepada Nabi Muhammad saw. Al-Kitāb ini meliputi isi mushaf, baik yang berbentuk nubüwah ataupun risālah.

${ }^{4}$ Ayat-ayat yang berisi ajaran-ajaran akhlak.

${ }^{5}$ Bentuk bahasa dan bunyi dari semua isi al-Qur'an.

${ }^{6}$ Suatu tempat yang di dalamnya terdapat hukum-hukum alam yang rinci sekaligus terjadinya peristiwaperistiwa dalam sejarah. Imām Mubin dapat diibaratkan sebagai RAM, bagian komputer yang bisa merekam, bisa ditulis, bisa dibaca, dan diubah. Ia akan selalu berubah walaupun tidak pernah keluar dari cakupan ROM.

${ }^{7}$ Suatu tempat yang di dalamnya dijumpai plan (rancangan, perencanaan) umum bagi alam. Lauh Maḥfūz mengandung hukum umum yang mengatur eksistensi dan sejarah. Dalam dunia komputer, ia bisa diibaratkan seperti ROM yang hanya bisa dibaca tetapi tidak bisa ditulis kembali ataupun diubah. Dengan kata lain Lauḥ Maḥfūz bersifat statis.
} 
ayat keempat merujuk kepada al-Qur'an bukan kepada Muhammad. Ini juga disebabkan karena surat al-Najm turun pada masa awal kenabian. ${ }^{8}$

Kedua, Sunnah qauliyah, yang mutawätir ataupun ähäd, tercatat dalam kitab-kitab hadis dan kitab lainnya hanyalah untuk menyenangkan hati dan perasaan saja. Ini disebabkan karena sunnah merupakan hukum-hukum, dan hukum-hukum itu bisa berubah seiring dengan perubahan zaman dan tempat. Satu-satunya tolok ukur untuk menerima hukum sunnah adalah sesuai atau sejaran dengan al-Qur'an dan realita kehidupan. Sedangkan hukum-hukum sunnah tidak akan diterima jika bertentangan dengan al-Qur'an.

Muḥammad Syaḥrūr menolak pendapat Ibn 'Ābidīn yang mengatakan bahwa apabila pendapat ulama-ulama kami berbeda dengan al-Qur'an dalam suatu hal maka kami akan mengambil pendapat ulama kami itu (in ta'äradha qaulun liashhääbinā ma'a qaul al-Qứàn fì

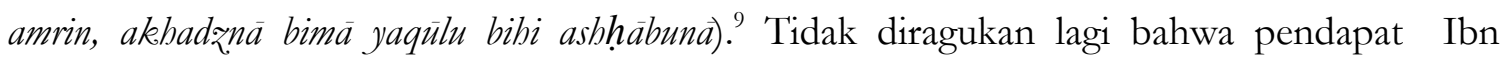
'Ābidīn ini jelas bertentangan dengan al-Qur'an. Hadis saja kalau tidak sejalan dengan alQur'an harus ditolak, apalagi pendapat ulama lainnya.

Ketiga, sunnah Nabi merupakan ijtihad pertama dan pilihan terbaik pertama untuk mengaplikasikan wahyu yang diterima pada saat itu. Tetapi ijtihad tersebut bukan akhir dari semua hal, dan bukanlah satu-satunya jalan keselamatan bagi realita kehidupan. ${ }^{10}$ Muhammad sebagai seorang mujtahid tentu bisa salah dan bisa juga benar ketika melakukan sesuatu. Sunnah dalam bentuk ijtihad tidak harus diikuti karena situasi dan kondisi pada masa itu berbeda dengan masa sekarang kita hidup. Tetapi yang harus diikuti adalah semangat dan metode Muhammad dalam melakukan ijtihad supaya sesuai dengan semangat zaman.

Keempat, sunnah nabawiyah merupakan cerminan kebenaran pertama yang mengikuti atau sesuai dengan al-Qur'an dan keadaan-keadaan saat itu. Tidak diragukan lagi bahwa sunnah nabawiyah merupakan hal yang ideal pada saat al-Qur'an diturunkan karena sesuai dengan situasi dan kondisi saat itu. Sunnah yang seperti bersifat nisbi (relatif) yang tentu bisa berkembang dan berubah seiring dengan perjalanan waktu. Sunnah-sunnah yang sudah dikodifikasi dalam berbagai macam bentuk disebut dengan hadis. Perlu penulis tegaskan bahwa sunnah dalam bahasa Muḥammad Syaḥrūr adalah hadis sebagaimana yang dikenal selama ini. Dalam kajian hadis memang tidak dibedakan antara sunnah, khabar, aśar, dan hadis. Semua dimaknai sama secara istilah Ulumul Hadis.

Dengan mengetahui konsep sunnah atau hadis Muḥammad Syaḥrūr di atas, bisa dikatakan bahwa pemahaman hadis harus dinamis dan kontekstual sesuai dengan perkembangan zaman. Titik penting konsep sunnah adalah ijtihad awal Muhammad saw. dalam mengatasi problematika pada saat itu. Sebagai seorang mujtahid, tentu apa yang dikatakan dan dilakukan bisa salah dan bisa benar. Itulah sebabnya dalam konteks sekarang pemahaman terhadap hadis harus menggunakan ilmu-ilmu saosial dan sains modern supaya pemahaman kita tidak kaku. Tidak hanya hadis yang harus dipahami seperti itu, al-Qur'an pun juga demikian. Dalam kaitannya dengan sunnah atau hadis, Muḥammad Syaḥrūr

${ }^{8}$ Muḥammad Syaḥrūr, Naḥw Ushūl Jadìdah li al-Fiqh al-Islāmī: Fiqh al-Mar'ah, (Syria-Damaskus: al-Ahālī li al-țibā'ah wa al-Nasyr wa al-Tauzī, cet-I, 2010), h. 62.

${ }^{9}$ Muḥammad Syaḥrūr, Naḥw Ușül Jadìdah li al-Fiqh al-Islämì, h. 63.

${ }^{10}$ Muḥammad Syaḥrūr, Naḥw Ușül Jadìdah li al-Fiqh al-Islāmì, h. 63. 
mengkaji konsep ketaatan dan kedudukan Muhammad saw. Hal ini pendting karena dengan mengetahui hal tersebut, seseorang bisa memahami hadis dengan benar.

\section{Ketaatan kepada Muhammad saw.}

Menurut Syahrūr, dalam al-Qur'an ada empat kata yang membentuk formulasi ketaatan (al-tăàa) yaitu al-ittibä', al-qudwah, al-sunnah, dan al-uswah. Dengan merujuk kepada Lisān al-'Arab dan Mu'jam Maqäyis al-Lugah, ia mengatakan bahwa sunnah berasal dari kata sanna yang berarti mengalir dengan mudah. Ini sesuai dengan ungkapan mämasnün yang bermakna yajri bisubülatin (mengalir dengan mudah). Sunnah juga bermakna jalan, metode, cara dan contoh (al-thariqah wa al-mitsā̄). Jika dikatakan bahwa istaqäma al-rajulu 'alà sananin wähidin, maknanya adalah 'alà țariqatin wa misälin wähidin. Demikian juga dengan kalimat banā al-qaumu buyütabum 'alā sunan wähid, maknanya adalah alà țariqatin wa mis̈äl wähid. ${ }^{11}$ Makna sunnah secara kebahasaan atau etimologi ini semua ulama juga berpendapat demikian, jadi tidak ada perbedaan sama sekali.

Perbedaan muncul ketika pemaknaan sunnah dalam bentuk aplikasi yang selama ini dipahami bersifat abadi oleh kaum Muslimin. Dengan merujuk kepada ayat-ayat al-Qur'an, seperti surat Āli Imrān [3]: 137, al-Nisā' [4]: 26, al-Anfāl; 38, al-Hijir; 13, al-Kahf; 55, alAḥzāb [33]: 38, Gāfir; 55, Muḥammad Syaḥūūr mengatakan bahwa makna sunnah di sini tidak bersifat abadi melainkan bisa berubah (nisbi atau relatif). Syahrūr membagi kosep sunnah menjadi dua bagian yaitu sunnah rasülȳah dan sunnah nabawìyah.

Sunnah rasülyyah merupakan risalah yang diturukan kepada Nabi Muhammad dalam bentuk wahyu. Sunnah bentuk ini terdapat dalam Umm al-Kitäb yang berupa pondasi-pondasi dasar, syi'ar-syi'ar, teori batas, amar makruf nahi munkar juga bersumber dari sunnah ini. Menurut Syahrūr, sunnah rasülīyah merupakan bentuk sunnah yang harus diikuti dan ditaati (majäl al-uswah, al-țäah, al-qudwah wa al-ittibā'). Konsep ini mirip dengan sunnab tasyrì̄yah dan sunnah gairu tasyrììyah yang digagas oleh Maḥmūd Syaltūt dan Yūsuf al-Qarāọāwīi. Sebenarnya konsep tersebut sudah ada dalam kitab-kitab ulama klasik meskipun belum sistematis.

Muḥammad Syaḥūr merupakan seorang pemikir kontemporer yang pemikiranpemikirannya dilandaskan dengan fenomena-fenomena yang ada di sekitarnya. Dalam memahami sebuah hadis, dia tidak serta merta mengaplikasikannya sebelum melihat situasi dan kondisi pada masa Nabi, kemudian dikontekstualisasikan pada masa sekarang. Dalam buku-buku yang ditulisnya, Syaḥrūr mengkritik pemahaman ulama-ulama klasik yang dijadikan rujukan oleh beberapa pemikiran modern kontemporer. Penting dicatat bahwa dalam memahami sebuah hadis, Syaḥrūr melihat konteks sosio-kultural, politik, ekonomi dan masalah-masalah yang sedang berkembang di masyarakat. Dalam menghadapi sebuah persoalan, kita tidak perlu merujuk kepada ulama-ulama klasik karena kerangka berpikir tiaptiap masa berbeda.

Pemahaman Muhammad Syaḥūr terhadap sebuah hadis sedikit banyak memiliki kemiripan dari pendahulunya, seperti Maḥmūd Syaltūt, Muḥammad al-Gazālī, bahkan bisa jadi Yūsuf al-Qarạ̄̂āwī. Dalam konteks Indonesia, pemikiran Syaḥrūr memiliki kemiripan dengan M. Syuhudi Ismail. Tentu diakui bahwa kedua tokoh ini belum saling mengenal

${ }^{11}$ Muḥammad Syaḥrūr, al-Sunnah al-Rasūtìyah wa al-Sunnah al-Nabawìyah; Ru'yatun Jadìdah (Beirut: Dār alSāqū, cet-I, 2012), h. 93. 
apalagi membaca karya masing-masing. Kalaupun ada kesamaan maka itu hanya kebetulan saja, dan hal ini bisa dibenarkan secara akademik.

Sebagaimana disebutkan di atas bahwa Muḥammad Syahrūr merupakan seorang pemikir Islam kontemporer yang berani sekaligus kontroversial dalam melontarkan wacana dalam beberapa bukunya. Di antara pemikiran atau pemahaman baru yang ditulisnya adalah tentang konsep sunnah. Pemaknaan dan pembagian sunnah yang dikemukakan Syaḥūr berbeda dengan sunnah menurut ulama-ulama terdahulu. Secara khusus dia membahas masalah ini dalam bukunya al-Sunnah al-Rasüliyah wa al-Sunnah al-Nabawiyab; Ru'yatun Jadidah. Selain di buku ini, Syahrūr juga membahas konsep sunnah atau hadis dalam bukunya lain, seperti Naḥwa Ușül al-Jadidah li al-Fiqh al-Mar'ah.

Kata tăa $a b$ berasal dari tiga huruf, țawa'a (ța', wau, dan ain) yang berarti ketundukan dan kepatuhan. Ketaatan tidak boleh dipaksakan kepada orang lain karena ia berasal dari keinginan seseorang. Di sinilah manusia bebas untuk memilih apa yang diinginkannya sesuai dengan firman Allah dalam surat Fușsilat ayat 11 yang artinya; Kemudian Dia menuju kepada penciptaan langit dan langit itu masih merupakan asap, lalu Dia berkata kepadanya dan kepada bumi: "Datanglah kamu keduanya menurut perintah-Ku dengan suka hati atau terpaksa". keduanya menjawab: "Kami datang dengan suka bati". ${ }^{12}$ Kalau kita merujuk kepada al-Qur'an, ketaatan yang diperintahkan kepada Nabi hanyalah dalam kedudukan belaiu sebagai Rasul. Itulah sebabnya dalam al-Qur'an sering ditemukan kata-kata ațiurrasü , tidak ditemukan ațínnnab $\vec{\imath}{ }^{13}$

Muhạmmad Syahrūr membagi konsep taat dalam al-Qur'an menjadi dua yaitu al-thäah al-muttashilah dan al-thä'ah al-munfashilah. Al-thä'ah al-muttashilah merupakan ketaatan kepada Rasul (bukan Nabi) yang langsung berhubungan dengan ketaatan kepada Allah (thäatur rasül muttashilah bithäatillah mubäsyarah). Ketaatan inilah yang bersifat kekal sampai hari kiamat, baik pada masa Rasul saw. maupun setelah kawafatan beliau. Ayat-ayat al-Qur'an yang menjadi argumen untuk ketaatan muttașilab ini adalah Q.S. Āli 'Imrān [3]: 132, ${ }^{14}$ al-Nūr [24]: $52,{ }^{15}$ dan al-Aḥzāb [33]: $71 .^{16}$

Sedangkan al-thäah munfashilah merupakan ketaatan kepada Rasul yang tidak berhubungan langsung dengan ketaatan kepada Allah. Dalam al-Qur'an memang ada beberapa ayat yang bisa dijadikan sebagai argumentasi untuk menguatkan pendapat demikian. Seperti Q.S. al-Nisā' [4]: 59, ${ }^{17}$ al-Mā’idah [5]: 92, ${ }^{18}$ dan al-Tagābun [64]: 12. ${ }^{19}$ ketaatan munfashilab hanya berlaku pada saat Nabi saw. masih hidup, kalau beliau sudah mati

\footnotetext{
${ }^{12}$ Redaksi ayat itu adalah

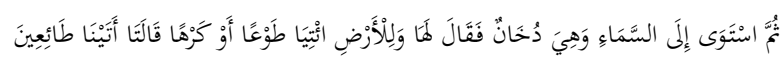

${ }^{13}$ Muḥammad Syaḥrūr, al-Sunnah al-Rasūilyah wa al-Sunnah al-Nabawìyah, h. 109.

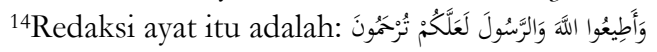

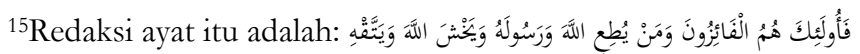

${ }^{16}$ Redaksi ayat itu adalah

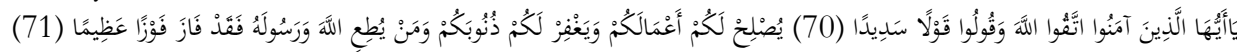

${ }^{17}$ Redaksi ayat itu adalah

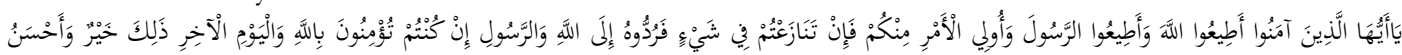

${ }^{18}$ Redaksi ayat itu adalah

${ }^{19}$ Redaksi ayat itu adalah

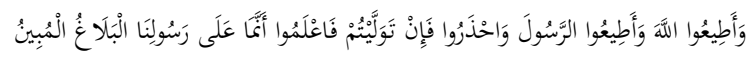

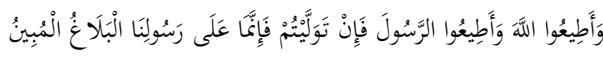


maka tidak ada ketaatan kepada beliau. Dalam pandangan Muḥammad Syaḥrūr, Nabi saw. hanya ma'sum dalam kedudukan beliau sebagai seorang Rasul (maqām al-risālah).

Adapun ketika menempati posisi kenabian (maqām al-nubūwab) maka Muhammad hanya sebagai seorang mujtahid. ${ }^{20}$ Sebagai seorang mujtahid tentu apa yang dilakukan dan disabdakan bisa saja salah. Namun harus diakui bahwa menentukan hadis-hadis yang nubuwah dan risalah memang agak sulit karena belum ada kriteria yang pasti dari sarjanasarjana Muslim lainnya.

1. Kedudukan Muhammad saw.

Dari penjelasan di atas bisa diketahui bahwa Muhammad Syahrūr membagi kedudukan Muhammad menjadi dua yaitu sebagai Nabi dan Rasul, dalam buku lain ditambah sebagai manusia biasa. Dalam buku Naḥw Ushül Jadìdah li al-Fiqh al-Islämì, Syahrūr mengatakan juga bahwa Muhammad sebagai manusia tidaklah maksum. ${ }^{21}$ Dia mengatakan bahwa:

$$
\begin{aligned}
& \text { فإذا نظرنا في سيرة الأنبياء الرسل السابقين لمحد وجدنا أن نبواقم وأدلتها من معجرات وكرامات, جاءت مستقلة } \\
& \text { عن رسالاقم التي ملوها من ربهم إلى الناس. أما النبي مُحمَّم (ص) فقد جاءه الوحي بالتنزيل متضمنا نبوته مع أدلتها ورسالته }
\end{aligned}
$$

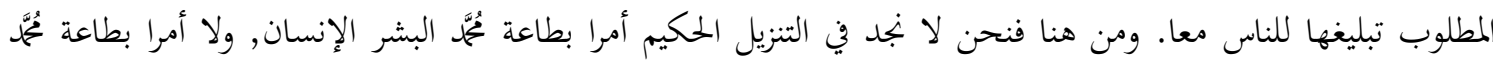

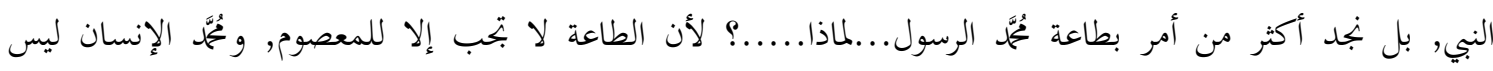

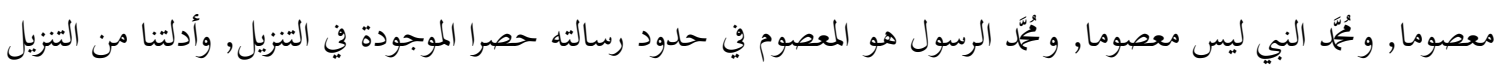

$$
\begin{aligned}
& \text { والأخبار أكثر من أن تحصى. }
\end{aligned}
$$

Dalam kitab-kitab ulama klasik, antara Nabi dan Rasul memiliki perbedaan. Nabi adalah seorang laki-laki dari golongan manusia yang diwahyukan oleh Allah dengan syari'at, akan tetapi tidak dibebankan/diperintah untuk menyampaikannya. Adapun Rasul adalah seorang laki-laki dari golongan manusia yang diwahyukan oleh Allah dengan syari'at dan diperintahkan untuk menyampaikannya (kepada umatnya masing-masing). ${ }^{23}$ Dengan demikian, pemisahan atau pembedaan terhadap kedudukan Muhammad saw. merupakan suatu hal yang biasa dikaji oleh ulama terdahulu.

Kajian-kajian tentang perbuatan Muhammad pun sudah dilakukan oleh sarjana-sarjana Muslim sebelum Syaḥrūr mengemukakan ide-idenya. Perbuatan Muhammad juga berimplikasi pada perbedaan dalam penerapan hukum Islam. ${ }^{24}$ Di Indonesia juga pernah dilakukan oleh M. Syuhudi Ismail, ${ }^{25}$ yang juga merupakan tokoh kajian hadis Indonesia

${ }^{20}$ Muḥammad Syaḥrūr, al-Sunnah al-Rasūtīyah wa al-Sunnah al-Nabawìyah, h. 111.

${ }^{21}$ Muḥammad Syaḥrūr, Naḥw Ușül Jadìdah li al-Fiqh al-Islāmì, h. 59.

${ }^{22}$ Muḥammad Syaḥrūr Naḥw Uṣūl Jadìdah li al-Fiqh al-Islāmì, h. 59.

${ }^{23}$ Jalāluddīn 'Abdur Raḥmān al-Suyūṭī, Tadrīb al-Rāñ fì Syarhi Taqrīb al-Nawawì (Bairut: Dār al-Kutub al'Ilmīyah, cet-I, 2009 M), h. 37-38. Muhạmmad 'Alî al-Ṣābūnī, al-Nubüwwah wa al-Anbiyā' (Mesir: Dâr al-Salâm, cet-I, 1417 H/1997 M), h. 17.

${ }^{24} \mathrm{Hal}$ ini sebagaimana dilakukan oleh Muhammad Sulaimān al-Asyqar dalam bukunya Af'äl al-Rasūl wa Dalālātuhā alā al-Ahkeàm al-Syar'ȳyah (Beirut: Mu'assasah al-Risālah, cet-VI, 1426 H/2003 M). Buku ini merupakan disertasi doktoral di Universitas al-Azhar Mesir, terdiri dari dua jilid.

${ }^{25}$ M.Syuhudi Ismail lahir di Lumajang, Jawa Timur, pada tanggal 23 April 1943. Setelah menamatkan Sekolah Rakyat Negeri di Sedorejo, Lumajang, Jawa Timur (1955), ia meneruskan pendidikannya ke Pendidikan Guru Agama Negeri (PGAN) 4 tahun di Malang (tamat 1959); Pedidikan Hakim Islam Negeri (PHIN) di Yogyakarta (tamat 1961); Fakutas Syari'ah, IAIN Sunan Kalijaga, Yogyakarta, cabang Makassar (kemudian menjadi IAIN Alauddin Makassar), berijazah Sarjana Muda (1965), Fakultas Syari'an IAIN Alauddin Ujung Pandang (tamat 1973), Studi Purna Sarjana (SPS) di Yogyakarta (Tahun Akademisi 1978/1979), Program Studi S2 Pada Fakultas Pascasarjana IAIN Syarif Hidayatullah Jakarta (tamat 1985), kemudian Program Doktoral pada Institut yang sama (tamat 1987). Disertasinya diterbitkan dengan judul "Kaedah Kesabihan Sanad Hadis: Telaah Kritis dan Tinjauan dengan Pendekatan Ilmu Sejarah." Sejak terbit buku ini banyak memberi wawasan dalam 
tahun 1990-an. Syuhudi Ismail mengatakan bahwa dalam sejarah, Nabi Muhammad saw. berperan dalam banyak fungsi.

Jika dipetakan, maka kedudukan Muhammad bisa dikelompokkan menjadi enam kategori, yaitu (a). sebagai Rasulullah, (b). kepala negara, (c). pemimpin masyarakat, (d). panglima perang, (e). hakim dan (f). sebagai pribadi. ${ }^{26}$ Bahkan pemikiran Syuhudi Ismail lebih rinci daripada Muḥammad Syaḥrūr. Bagi Syaḥrūr Muhammad hanya menjadi mujtahid ketika menjadi Nabi sehingga bisa saja keliru dalam melakukan suatu hal. Ketika menempati posisi sebagai rasul maka akan terpelihara dari kesalahan atau maksum. ${ }^{27}$

Ketika membahas tentang posisi atau kedudukan Muhammad sebagai mausia biasa, Rasul dan Nabi, Muḥammad Syaḥrūr memberikan contoh-contoh yang cukup banyak. Sebagai manusia tentu Muhammad tidak bisa lepas dari lingkungan sekitar yang mengitarinya. Sebagai makhluk biologis, beliau butuh makan, minum, tidur, berolah raga, dan hal lainnya yang terkait dengan sisi kemanusiaan. Hadis yang bersumber dari Muhammad sebagai manusia biasa tidak memiliki kaitan hukum syariat sama sekali.

Hadis-hadis terkait dengan kedudukan Muhammad sebagai manusia sangat banyak dan sama sekali tidak ada tuntutan untuk diikuti. Dalam pengertian bahwa kita boleh mengikuti dan boleh tidak karena tidak terikat dengan hukum sama sekali. Bahkan ada juga yang dilarang untuk diikuti, misalnya puasa wișal, lama berdiri ketika shalat sendirian, dan sebagainya. Di antara contoh hadis sisi kemanusiaan Muhammad adalah menjilat jari setelah makan, cara beliau berjalan, ${ }^{28}$ demikian juga dengan jenis pakaian, makanan yang disenangi Muhammad dan sebagainya.

Muḥammad Syaḥrūr memberikan contoh-contoh hadis yang terkait dengan kedudukan Muhammad saw., baik sebagai Nabi, Rasul ataupun sebagai manusia biasa. Hadis-hadis risälah (sunnah risälah) berlaku universal bisa diterapkan kapan dan di manapun, baik pada saat Muhammad saw. masih hidup maupun setelah wafat. Kebanyakan hadis risālah berisi tentang harkat martabat kemanusian dan syi'ar agama. Kalau hadis itu bertentangan dengan nilai-nilai kemanusian misalnya maka harus ditolak. Salah satu contohnya adalah: ألمسلم من سلم الناس من لسانه ويده, tanpa disebutkan siapa periwayatnya dan di kitab mana hadis tersebut dicantumkan. ${ }^{29}$ Setelah penulis teliti ternyata hadis tersebut terdapat dalam Șậh al-Bukhärì dengan redaksi:

kajian hadis Nabi. Syuhudi wafat pada hari Ahad 19 November 1995 M. Lihat biografi singkat beliau dalam buku Kaedah Kesabihan Sanad Hadis: Telaab Kritis dan Tinjauan dengan Pendekatan Ilmu Sejarah (Jakarta: Bulan Bintang, cet-III, 1426 H/2005 M), h. 269-270.

${ }^{26}$ Lihat M. Syuhudi Ismail, Hadis Nabi yang Tekstual dan Kontekstual: Telaah Ma'anil al-Hadts tentang Ajaran Islam Universal, Temporal dan Lokal (Jakarta: Bulan Bintang, cet-I, 1415 H/1994 M), h. 4.

${ }^{27}$ Muḥammad Syahrūr, Tajfîf Manābi' al-Irbāb (Syria-Damaskus: al-Ahālī li al-ṭibā’ah wa al-Nasyr wa alTauzī, cet-I, 2008), h. 24. Tetapi jauh sebelumnya, juga ada ulama yang melihat posisi atau kedudukan Muhammad dan pembagian sunnah seperti Syaḥrūr. Al-Qarrāfī (w. $684 \mathrm{H}$ ) dalam bukunya al-Iḥkām fì Tamyìz. al-Fatāwā an al-Ahkeàm wa Tașaruffät al-Qạ̈ì wa al-Imām, dan al-Furūq, Syah Waliyullāh al-Dihlawī (w. 1176 H), Muḥammad Sulaimān al-Asyqar dalam bukunya Af'āl al-Rasūl wa Dalālātuhā fì al-Ahkeàm al-Syarìah.

${ }^{28}$ Muhammad Syahrūr, al-Sunnah al-Rasülìyah wa al-Sunnah al-Nabawiyah, h. 163.

${ }^{29}$ Muḥammad Syahrūr, al-Sunnah al-Rasülīyah wa al-Sunnah al-Nabawìyah, h. 165.

${ }^{30} \mathrm{Nama}$ lengkap kitab ini adalah al-Jämi' al-Ṣaḥ̄h al-Musnad min Hadīs Rassūlillāh Ṣallallāhu 'alaihi wa Sallam wa Sunanibi wa Ayyāmihi atau al-Jämi' al-Musnad al-Ṣahịh al-Mukhtashar min Umüri Rassülilläh Șallallähu 'alaibi wa Sallam wa Sunanihi wa Ayyāmihi. 


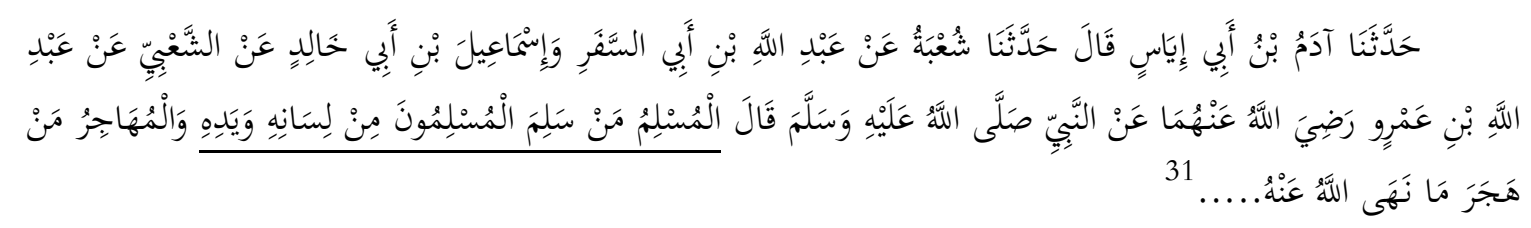

Dari 'Abdullah bin 'Amr, dari Nabi saw. bersabda: "Seorang muslim adalab orang yang kaum Muslimin selamat dari lisan dan tangannya, dan seorang Mubajir adalah orang yang meninggalkan apa yang dilarang oleh Allah"

Hadis di atas berlaku universal, kapan dan di manapun. Kalau kita tidak ingin diganggu orang lain maka jangan mengganggu, kalau sakit dicubit maka jangan mencubit. Tetapi penulis tidak menemukan redaksi matan dengan kata al-nās sebagaimana yang disebutkan Syahrūr di atas. Semua matan hadis menyebutkan kata al-muslimüna, bukan al-nās jika memakai redaksi seperti di atas. Ini merupakan salah satu kelengahan atau keteledoran Syahrūr dalam mengutip hadis Nabi karena tidak merujuk kepada sumber primer (lihat misalnya Șahịh al-Bukhärī, no. 10 dan 6003). ${ }^{32}$

Dari sekian riwayat yang ada tidak satupun matan hadis memiliki redaksi sebagaimana disebutkan Muḥammad Syaḥrūr. Aḥmad (w. 241 H) memang menyebutkan redaksi al-nas, tetapi tidak seperti matan redaksi hadis di atas. Beliau mengatakan (Musnad, no. 6464):

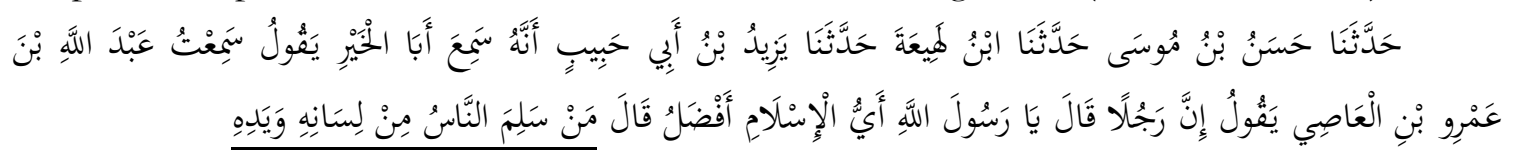

.........'Abdullah bin 'Amr bin al-ās berkeata: babwa seorang lelaki bertanya kepada Rasulullah saw. "Wahai Rasulullah, Islam yang bagaimana yang paling baik?" Beliau menjawab: "Yaitu seseorang yang orang lain selamat dari keburukean lisan dan tangannya."

Sedangkan hadis nubüwah tidak bersifat universal melainkan relatif, bisa diikuti dan bisa juga ditinggalkan tetapi masih ada kaitannya dengan ibadah. Hadis-hadis seperti ini lebih banyak berbicara tentang kemasyarakatan, politik, ekonomi, pendidikan, dan peraturanperaturan yang berlaku di masyarakat. Di antara contoh hadis nubuwah adalah hadis-hadis yang berhubungan dengan pernikahan, talak, dan hal-hal yang mengatur hubungan kemasyarakatan. Salah satu contohnya adalah hadis yang berbunyi:

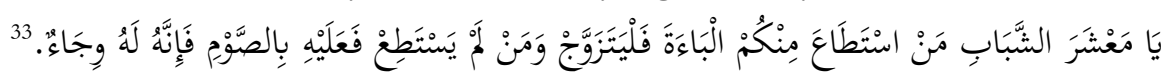

"Wabai sekalian pemuda, siapa di antara kalian yang telab mempunyai kemampuan, maka hendaklah ia menikah, dan barangsiapa yang belum mampu, bendaklah ia berpuasa karena hal itu akan lebih bisa meredakan gejolaknya"

Muhammad Syahrūr memberikan banyak contoh tentang hadis nubuwah dengan berbagai ragam redaksi. Menurutnya, hadis yang terkait dengan posisi Muhammad sebagai

${ }^{31} \mathrm{Abū}$ 'Abdillāh Muḥammad bin Ismā̄̄il bin Ibrāhīm bin al-Mugīrah bin Bardizbah al-Bukhārī, al-Jāmi' al-Sahịh, no. 9, Software Mausü'ah Hadis al-Kutub al-Tis'ah.

${ }^{32} \mathrm{Hadis}$ di atas diriwayatkan secara makna melalui banyak jalur tetapi intinya sama, lihat misalnya dalam Sahịh Muslim, no. 57, Sunan al-Nasā'̄̄, no. 4910, Sunan Abì Däwud, no. 2122, Musnad Ahmad, no. 6199, 6225, 6464, 6502, 6515, 6521, 6541, 6618, 6659, 6687, 6721, dan 6787, demikian jugan dalam Sunan al-Därimì, no. 2600 .

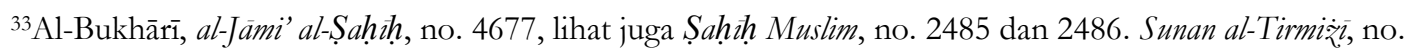
1001, Sunan al-Nasā̄ò, no. 2207-2211 dan 3156-3159, Sunan Abì Dāwud, no. 1750 dan 1835, Musnad Ahmad, no. 3411, 3819, 3830, 3903 dan 4050, Sunan al-Därimì, no. 2071 dan 2072. Software Mausū'ah Hadis al-Kutub alTis'ah 
Nabi tidak bisa dijadikan sumber syariat sebagaimana hadis hadis rasul (sunnah risalab) meskipun sesuai dengan al-tan₹ill al-ḥakim (al-Qur'an). Ini disebabkan karena hadis nabi hanya bersifat khusus yang ditujukan kepada orang-orang tertentu. ${ }^{34}$ Menikah memang anjuran agama dan perbuatan yang dipraktikkan langsung oleh Muhammad saw. Tetapi kaum muslimin tidak harus menikah kalau memang bisa menjaga pandangan dan nafsu syahwat untuk tidak terjerumus kepada perbuatan haram (zina).

Terakhir adalah hadis yang bersumber dari Muhammad sebagai manusia biasa sebagaimana manusia lainnya. Sebagai manusia, tentu Muhammad tidak bisa lepas dari lingkungan sekitar yang mengitarinya. Sebagai makhluk biologis tentu beliau butuh makan, minum, tidur, berolah raga, dan hal lainnya yang terkait dengan sisi kemanusiaan. Hadis yang bersumber dari Muhammad sebagai manusia biasa tidak memiliki kaitan hukum syariat sama sekali. Hadis-hadis terkait dengan kedudukan Muhammad sebagai manusia biasa sangat banyak dan sama sekali tidak ada tuntutan untuk diikuti. Dalam pengertian bahwa kita boleh mengikuti dan boleh tidak karena tidak terikat dengan hukum sama sekali. Bahkan ada juga yang dilarang untuk diikuti, misalnya puasa wisal, lama berdiri ketika shalat sendirian, dan sebagainya.

\section{Analisis Kritis Terhadap Muḥammad Syaḥrūr}

Konsep pemikiran sunnah Muḥammad Syahrūr menurut penulis masih belum jelas karena lebih banyak dititikberatkan pada ayat-ayat al-Qur'an. Contoh-contoh yang dipaparkan dalam buku al-Sunnah al-Rasüliyah wa al-Sunnah al-Nabawiyah belum mencerminkan hermeneutika pemahaman terhadap sunnah secara komprehensif. Jika sunnah dipahami dalam terminologi ulama hadis maka maknanya sama dengan hadis itu sendiri, yaitu perkataan, perbuatan, ataupun ketetapan yang bersumber dari Nabi saw. Sebenarnya pembagian kedudukan Muhammad sebagai Nabi dan Rasul bukanlah yang baru dalam studi hadis, tetapi sebelum Syahrūr konsep itu sudah ada meskipun dengan bahasa yang berbeda. Demikian juga dengan tindakan Nabi saw. apakah itu syariat atau bukan juga sudah dibahas oleh sarjana-sarjana Muslim.

Dalam pembacaan penulis terhadap buku al-Sunnah al-Rasüliyah wa al-Sunnah alNabawiyah dan buku-buku Syaḥūr lainnya, bisa disimpulkan bahwa yang menjadi pijakan Syahrūr dalam membahas konsep sunnah dan hal-hal yang berkaitan dengannya adalah ayatayat al-Qur'an, bukan hadis. Ini tidak mengherankan karena memang dia merupakan ahli dalam kajian studi al-Qur'an. Bisa dikatakan bahwa dalam pandangan Syahrūr sebuah hadis akan diterima kalau tidak bertentangan dengan nilai-nilai Qur'ani. Hal itulah yang juga dilakukan oleh sarjana-sarjana Muslim sebelumnya, seperti Muḥammad al-Gazālī (w. 1996 M) dan Yūsuf al-Qarāọāwī misalnya.

Ada beberapa hal yang penulis perhatikan dari pemikiran Muḥammad Syaḥrūr yang belum diuraikan oleh peneliti-peneliti sebelumnya.

1. Memahami Hadis dengan Pendekatan Sejarah

Muhammad Syahrūr memang tidak secara eksplisit menyebutkan langkah-langkah atau metode dalam memahami hadis Nabi. Tetapi dari penjelasan dalam beberapa karyanya jelas mengindikasikan bahwa hadis-hadis itu harus dilihat dari segi masanya. Dalam istilah Ulumul Hadis disebut dengan asbäb al-wurüd. Syahrūr mengakui bahwa keadaan pada masa Nabi dan sahabat kurang mampu untuk berdialog dengan masa sekarang. Bahkan mustahil kita yang hidup pada abad 21 bisa kembali kepada masa Nabi yang hidup pada abad 7 M. ${ }^{35}$ Karena itu

${ }^{34}$ Muhammad Syahrūr, al-Sunnah al-Rasülīyah wa al-Sunnah al-Nabawìyah, h. 168.

${ }^{35}$ Muḥammad Syaḥrūr, al-Sunnah al-Rasülìyah wa al-Sunnah al-Nabawiyah, h. 27. 
kita tidak bisa memahami hadis secara literal atau tektual tetapi harus kontekstual. Bahkan kontekstual juga tidak cuku tetapi harus dikontekstualisasikan kepada masa sekarang.

2. Memahami Hadis Sesuai dengan Semangat Zaman

Sudah dijelaskan di atas bahwa dalam memahami hadis Nabi saw. harus memperhatikan situasi dan kondisi yang berkembang di masyarakat. Pendekatan kontekstual sangat diperlukan dalam memahami suatu hadis supaya tidak terjadi distorsi terhadap pemaknaannya. Memang diakui bahwa beberapa karya-karya ulama klasik harus dipahami secara kritis, bahkan ada beberapa hal yang harus dibuang karena tidak sesuai dengan dengan zaman yang ada sekarang ini. Dalam memahami al-Qur'an dan hadis, Syaḥrūr menggunakan ilmu-ilmu modern seperti sosiologi, antropolgi, matematika, dan ilmu-ilmu yang berkembang pada masa modern lainnya. Intinya dalam memahami sebuah hadis harus sesuai dengan semangat zaman supaya bisa dikontekstualisasikan dengan kehidupan umat Islam sekarang.

3. Bersifat Humanis

Memanusiakan manusia merupakan salah satu ajaran Islam yang memiliki peran penting dalam kehidupan manusia. Jika ada hadis yang bertentangan dengan al-Qur'an menyangkut nilai-nilai kemanusiaan maka harus ditolak. Muhammad Syahrūr menolak hadis yang dinilai merendahkan derajat wanita meskipun itu sahih, misalnya hadis riwayat al-Bukhārī (no. 2646), Muslim (no. 4128) dan lainnya dari Ibn 'Umar yang berbunyi:

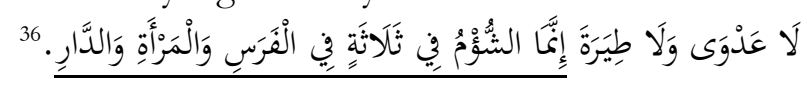

"Tidak ada penyakit yang menular secara sendirian, tidak ada pengarub atau alamat jahat pada suara burung. Sesunggubnya kesialan ada pada tiga hal, pada kuda, wanita dan tempat tinggal".

Muhammad Syaḥūr mempertanyakan hadis tersebut, apakah mungkin Muhammad menyamakan antara binatang yang tidak berakal (kuda), makhluk yang berakal (wanita) dan barang yang tidak bergerak sama sekali (rumah)? Tentu jawabannya tidak karena bisa dinilai merendahkan derajat kemanusiaan. ${ }^{37}$ Secara tidak langsung Syahrūr ingin memperjuangkan hak-hak perempuan dan memerdekaan mereka hegemoni kaum laki-laki. Pemikiran Syahrūr tidak lepas dari pengaruh dunia pendidikannya di Irlandia (Dublin), tempat mengajar (Syria, Damskus), dan literatur-literatur yang dibaca.

Ketika belajar di Eropa, tentu Syaḥrūr terpengaruh juga ide-ide filsafat Barat dan kajian bahasa yang diterima dari gurunya, Ja’far Dakk al-Bāb. Di Syiria dia bertemu dengan pemikiran-pemikiran ulama yang dianggap klasik yang seolah-olah mendominasi peran wanita. Demikian juga dengan literatur-literatur yang dibaca di dunia Barat, yang sangat mempengaruhi corak pemikiran Syahrūr. Jika diperhatikan dengan seksama, nampaknya Syaḥrūr kurang memperhatikan asbäb al-wurüd suatu hadis karena dia langsung mengkaji matan hadis.

\section{Simpulan}

Demikianlah tulisan singkat ini membahas pemikiran Muḥammad Syaḥrūr, terutama sekali yang tertulis dalam bukunya al-Sunnah al-Rasüliyah wa al-Sunnah al-Nabawiyah; Ru'yah Jadidah. Dalam buku ini dia menggunakan kata sunnah karena lebih umum dari pada hadis. Sebelum dibukukan hadis memang disebut dengan sunnah sebagaimana buku al-Sunnah Qabla al-Tadwin oleh Muḥammad 'Ajjāj al-Khațīb.

Selain itu, kata sunnah lebih melekat dengan hukum Islam dari pada kata hadis, seperti slogan yang sering kita dengar "Kembali kepada al-Qur'an dan Sunnah (back to the Quran and the sunnab)". Ulama-ulama muta'akhkhirin juga lebih suka menggunakan kata sunnah

${ }^{36}$ Lihat juga Sahịh Muslim, no. 4127-4130, Sunan al-Tirmiž̀, no. 2749, Sunan al-Nasä’̀, no. 3512-3513, Sunan Abi Däwud, no. 3421, Sunan Ibn Mājah, no. 1985 dan 3530, Muwațta’ Mālik, no. 1538.

${ }^{37}$ Muḥammad Syaḥrūr, al-Sunnah al-Rasūilyah wa al-Sunnah al-Nabawìyah, h. 165. 
daripada hadis, seperti Mușțafā al-Sibā'ī menulis buku al-Sunnah wa Makānatubā fì al-Tasyñ̄’ alIslämì, Muḥammad al-Gazālī al-Sunnah al-Nabawìyah Baina Abl al-Fiqh wa Abl al-Hadìts, Yūsuf

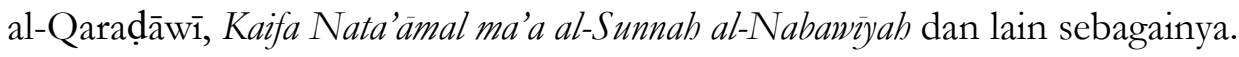

Dalam memahami suatu hadis, Syaḥrūr lebih menekankan kepada posisi Muhammad saw. itu sendiri, yang dibagi menjadi tiga posisi pokok yaitu sebagai manusia biasa, Nabi dan Rasul. Sebagai manusia biasa, apapun yang dilakukan oleh Muhammad tidak harus diikuti karena tidak terikat dengan hukum syariat sama sekali. Sebagai seorang Nabi juga tidak mutlak diikuti karena apa yang beliau lakukan dan sabdakan terkait dengan kasus dan orang tertentu. Dalam pengertian bahwa ia bersifat lokal temporal bukan mutlak absolut karena Nabi tidak bersifat maksum. Adapun ketika Muhammad sebagai Rasul, maka semua ucapan dan tindakannya harus diikuti karena Rasul itu maksum. Itulah sebabnya tindakan dan ucapannya bersifat universal.

Muḥammad Syaḥrūr membagi ketaatan kepada Muhammad menjadi dua yaitu munfashilah dan muttashilah. Al-thäah al-munfashilah merupakan ketaatan kepada Muhammad yang tidak terkait langsung dengan ketaatan kepada Allah. Sedangkan al-thäah al-muttashilah merupakan ketaatan yang langsung berhubungan kepada Allah. Menurut hemat penulis, hal ini merupakan pemikiran yang baru dalam kajian hadis karena ulama-ulama sebelum tidak pernah memetakannya secara eksplisit.

Apa yang dilakukan dan disabdakan Muhammad tidak harus ditaati karena tidak semua terkait dengan hukum syariat. Sebagaimana disebutkan di atas bahwa Muhammad ada kalanya sebagai manusia biasa, Nabi, dan Rasul. Tetapi untuk melihat posisi-posisi ini memang agak sulit karena tidak semua hadis memiliki asbāb al-wurūd sebagaimana tidak semua ayat al-Qur'an memiliki asbāb al-nuðül.

Kajian tentang pemikiran hadis Syaḥrūr memang perlu diteliti secara lebih mendalam karena memang ada beberapa poin yang menarik untuk dikaji. Nuansa pemikiran Syahrūr lebih kritis daripada pemikir-pemikir Muslim lainnya yang lebih bersifat ideologis dan apologis. Dalam mengkaji al-Qur'an dan hadis dia sama sekali tidak terikat dengan mazhab dan tanpa ada beban apapun sehingga pemikirannya lebih bebas, kritis, dan bertanggungjawab. Semoga tulisan singkat ini bermanfaat, saran, masukan, dan kritikan yang konstruktif sangat diharapkan dari para pembaca untuk penulisan hari-hari berikutnya.

\section{Daftar Pustaka}

Aḥmad, Abū 'Abdullāh Aḥmad bin Muḥammad bin Ḥanbal al-Syaibānī al-Marwazī, Musnad Ahmad, CD ROM Mausū'ah al-Hadis al-Syarîf.

Al-Munajjad, Māhir, (2008). Membongkar Ideologi Tafsir Al-Qur'an Kontemporer, trj. Burhanuddin Dzikri, Yogyakarta: Elsaq Press, cet-I.

Al-Asyqar, Muḥammad Sulaimān, $(1424$ H/2003 M), Af'āl al-Rasūl wa Dalālātuhà fì al-Aḥkām al-Syari’ah, Beirut: Mu'assasah al-Risālah, cet-VI..

Al-Nasā'̀, Abū 'Abdur Raḥmān Aḥmad bin Syu'aib bin 'Ali bin Sinān bin Baḥr, al-Sunan alSugrā, CD ROM Mausū'ah al-Hadis al-Syarīf.

Al-Ṭaḥhān, Mạ̣mūd, Taisìr Mushthalah al-Hadìts, Beirut: Dār al-Fikr, t.th.

Al-Tirmiżī, Abū 'Īsā Muḥammad bin 'Īsā bin Saurah bin Mūsā, al-Jāmi' al-Mukhtaṣar min alSunan 'an Rasūtillāh Sallallāhu 'Alaibi wa Sallam, (2004), CD ROM Mausū'ah al-Ḥà̄ì alSyarīf.

Fanani, Muhyar, Fiqih Madani: Konstruksi Hukum Islam di Dunia Modern, Yogyakarta: LKiS, cet-I. 
Ibn Mājah, Abū 'Abdullāh Muḥammad bin Yazīd bin Mājah al-Qazwainī, Sunan Ibn Mājah, CD ROM Mausū'ah al-Hadis al-Syariff.

Ismail, M. Syuhudi, (1426 H/2005 M). Kaedah Kesabihan Sanad Hadis: Telaah Kritis dan Tinjauan dengan Pendekatan Ilmu Sejarah, Jakarta: Bulan Bintang, cet-III. (1992 M). Metodologi Penelitian Hadis Nabi, Jakarta: Bulan Bintang, cet-I. (1995 M/1415 H). Hadits Nabi Menurut Pembela, Pengingkar dan Pemalsunya, Jakarta: Gema Insani Press, cet-I.

Jakfar, Tarmizi M, (2001). Otoritas Sunnah Non-Tasyri'iyyah Menurut Yusuf al-Qaradhawi, Yogyakarta: Ar-Ruzz Media, cet-I.

Muslim, Abū Al-Husain Muslim bin al-Hajajāj bin Muslim al-Qusyairī al-Naisābūrī,, al-Sahīh al-Mujarrad al-Musnad ilà Rasülillāh Șallallähu 'alaibi wa Sallam atau al-Musnad al-Sahịh alMukhtașar min al-Sunan bi al-Naqli al-Adli an Rasülilläh Șallalläbu 'alaibi wa Sallam, CD ROM Mausū'ah al-Hadīì al-Syarīf.

Syaḥrūr, Muḥammad, al-Kitāb wa al-Qur'ān: Qiräah Mu'așirah, Syria-Damaskus: al-Ahālī li alțibā'ah wa al-Nasyr wa al-Tauzī, t.th. , (1996). al-Islām wa al-İmān: Manẓūmah al-Qiyam, Syria-Damaskus: al-Ahālī li alțibā'ah wa al-Nasyr wa al-Tauzī.

, (2008). Tajfíf Manābi' al-Irhāab, Syria-Damaskus: al-Ahālī li al-țibā’ah wa alNasyr wa al-Tauzī, cet-I.

al-Daulah wa al-Mujtama', Syria-Damaskus: al-Ahālī li al-țibā'ah wa al-Nasyr wa al-Tauzī.

(2010). Nahw Ușūl Jadìdah li al-Fiqh al-Islämi: Fiqh al-Mar'ah, Syria-Damaskus: alAhālī li al-țibā’ah wa al-Nasyr wa al-Tauzī, cet-I.

Syaltūt, Maḥmūd, (1421H/2001M), al-Islām: 'Aqìdah wa Syarìah, Kairo: Dār al-Syurūq, cetXIV. 

Muhammad Anshari

Kedudukan 31 